DOI: 10.35218/armca.2020.1.05

\title{
Analysis of Ardabil's Business and Communication Routes in Survival and Prosperity Based on Historical Texts and Archaeological Data
}

\author{
Mehdi Hosseini Nia*, Karim Hajizadeh**, \\ Habib Shahbazi Shiran ${ }^{* * *}$, Reza Rezalou ${ }^{* * * *}$
}

\begin{abstract}
In the early Islamic centuries, Ardabil is considered to be the oldest and the first city in the Azerbaijani province due to its regional biodiversity in geographical texts. The present study investigates the communication routes to the peripheral points in the Islamic period and their role in the survival of the city based on historical literature and archeological data. The importance and safety of roads and communication routes were two important components that influenced each other, making Ardabil a city in the center of commercial and trading routes in the North-West. This situation can be seen and prosecuted during the Islamic period from the beginning of Islam to the late Islamic centuries. The research method is historical-analytical and the data were collected through the study of historical and geographical literature and the use of the archaeological reports of the area. The main question of this article is: "What effect did the communication routes have had on the survival of the Islamic period until the end of the Safavid period?" The results show that in the early centuries, the city's communication routes were significantly prosperous. The description of the roads and the importance of the buildings and the cities inside them are described together. In this period, roads have played a leading role in the survival and prosperity of the city. In the Middle Ages, this city became a trivial city in the region as the capital, trade and communication routes changed. During the Safavid period, the city was once again restored to its former prosperity due to the importance of the tomb complex of Sheikh Safiad-din Ardabili to the kings of the dynasty as well as the conversion of the city to the site of the Silk Road. During this period, numerous routes were created and led to the orientalists and tourists' travelling to this ciy.
\end{abstract}

Keywords: Ardabil city, historical texts, travelogues, business routes, communication routes

\footnotetext{
* PhD student of the Archaeology of Islamic Periods, University of Mohaghegh Ardabili, Faculty of Literature and Human Sciences, Mehdihosseyni5518@uma.ac.ir

** Coressponding author, assistant professor, Department of Archaeology, Faculty of Archaeology, University of Mohaghegh Ardabili, Ardabil, Iran, k_hajizadeh@uma.ac.ir ${ }^{* * *}$ Assistant Professor of the Department of Archaeology, University of Mohaghegh Ardabili, Ardabil, shahbazidahabib@uma.ac.ir

${ }^{* * * *}$ Associate Professor, Department of Archaeology, University of Mohaghegh Ardabili, Iran, rezarezaloo@yahoo.com
} 


\section{Introduction}

Ardabil has long been on the route of Azerbaijan-Gilan communication, as well as the connecting bridge between Zanjan province from Sarcham route to the border town of Parsabad and Azerbaijan. The four main communication routes in four geographic directions to the surrounding cities and adjacent provinces constitute the main morphology of the city. The communication axis of the western part, which today is the most important bridge connecting Ardabil to Sarein, Nair, Sarab and Tabriz with the eastwest direction, had the greatest impact on the growth and development of the city, even though the city along this axis had the biggest physical development ${ }^{1}$. Ardabil had a significant economic and commercial prosperity in the early centuries until the $4^{\text {th }}$ century, as it was geographically regarded as the most important capital and the first capital of Azerbaijan ${ }^{2}$. It has also been discussed in terms of its superior political status in the early centuries among the cities of the State of Azerbaijan ${ }^{3}$. From the $5^{\text {th }}$ century until the establishment of the Safavid rule, the city has lost some of its former prosperity, so that there is no further mention of the importance of this city, but in the Safavid period, the city was restored to its former prosperity, because of the importance of Sheikh Safi 's tomb complex for the kings of that period. During this period, travellers and orientalists went more to the city, which again stimulated and improved their communication paths. Ardabil's strategic position during historical periods has given rise to numerous trading routes and consequently provided many midway facilities in the region. Considering the importance of Ardabil in the archeological studies of the Islamic era and its role in commercial and cultural exchanges, as well as numerous references to historical geographical texts and travelogues, referred to as communication crossroads, identifying routes to surrounding cities and regions was essential based on geographical texts and archaeological data. The main questions of this article are the following two: 1. Why was Ardabil formed in this geographical location? and 2. What role did commercial roads play in the formation and survival of Ardabil during the Islamic era?

\footnotetext{
${ }^{1}$ Mohammad Reza Eqbal-Kuraim, Mohammad Soleimani Mehranjani; Musa Kamanroodi Kajvari; Ahmad Zanganeh, Explaining the Spatial Structure of the City and the Formation of Sub-Centers in Ardabil, 2019, p. 311.

2 Al-Yaqubi Ahmad ibn Abi Yaqub, Al-Baladan, 1965; Abolghasem Mohammad Ibn Hawqal, The face of the Earth, 1988 ; Abu Ishaq Ibrahim Istakhri, Book of Roads and Kingdoms, 1990.

3 Abdu'l-Allah Muhammad ibn Ahmad Moqaddasi, The Best Divisions for Knowledge of the Regions (Fourth Century), 1983 ; Al-Yaqubi Ahmad ibn Abi Yaqub, op. cit.; Abolghasem Mohammad Ibn Hawqal, op. cit. ; Istakhri, Abu Ishaq Ibrahim, op. cit.
} 


\section{Research Methodology}

This research has been done with a historical and documentary approach and the method of data collection has been descriptive, using the travelogues and geographical texts of Islamic era. Also, according to the subject matter, the report of the archeological excavations of the area has been used for proper analysis. In this research, the business and communication routes in the formation and survival of Ardabil city during the Islamic period were studied through two groups of sources including historical texts and archeological findings and with a comparative approach along with factors such as environmental geographical conditions, the location of the geological place. Political and cultural boundaries have been explored.

\section{Background of archeological studies and excavations in Ardabil}

Asgari Namin ${ }^{4}$, in his book entitled Ardabil in Oriental Travelogues with the Lives of European Tourists examined and described these travelogues, as well as the biography of the tourists who came to Ardabil. Shah Mohammad Ardabili ${ }^{5}$, in his book entitled From Artaville to Ardabil, studied the history of the formation of Ardabil city in the works of historians, Orientalists, and internal scholars. The book also contains the oldest pictorial documents of Ardabil and its buildings. Javadi $^{6}$, in his book entitled Descriptive Bibliography of Ardabil Province (Part I) described the name of the city in encyclopaedic texts, public books, and dedicated resources about Ardabil. Moreover, among the most important archaeological excavations and field visits in Ardabil province, the following can be mentioned: the excavations of the Islamic city of Owltan Qalasi in Moghan plain ${ }^{7}$, the author Abdul Hamid Mohajeri Nejad became acquainted with the book of excavations of this place, the most important city of the Aras River in the Sassanid and early Islamic period. The pre-revolutionary archeological studies of Ardabil province in Islamic period are limited to three chapters of excavation on Jome mosque in Ardabil ${ }^{8}$. After the revolution which lasted up to the eighty decade, archeological studies of the Islamic era focused on Ardabil buildings such as Jome Mosque ${ }^{9}$ and Sheikh Safi-ad-din Ardabili

\footnotetext{
${ }^{4}$ Yahya Asgari Namin, Ardabil in Orientalist Travelogues with the Lives of European Tourists, 2014.

${ }^{5}$ Rahman Shah Mohammad Ardabili, From Artaville to Ardabil, 2016.

${ }^{6}$ Seyed Mehdi Javadi, The Descriptive Bibliography of Ardabil Province (First Section), 2010.

${ }^{7}$ Karim Alizadeh, Preliminary Report on the Archaeological Excavations at Owltan Qalasi, Moghan Plain of Ardabil, 2007; Abdul Hamid Mohajeri Nejad, Report on Exploring the Oltan Castle of Moghan, 2007.

${ }^{8}$ Ali Akbar Sarfaraz, Report on the Exploration of Jome Mosque of Ardabil, 1975; Bahman Kargar, Report on the Exploration of Jome Mosque, 1975.

${ }^{9}$ Habib Shahbazi Shiran, Surveying and Analyzing the Architectural Elements and Jome Mosque of Ardabil, 2004.
} 
collection ${ }^{10}$. The excavation of the tomb of Sheikh Safi-ad-din Ardabili ${ }^{11}$ has led to the speculation of the Safavid caravanserai of Qanli Bolagh ${ }^{12}$. Given the importance of Ardabil city in the archeological studies of the Islamic era and its role in the commercial and cultural exchanges referred to as "the communication intersection", the identification of gates and routes to the surrounding cities and adjacent areas based on texts, travelogues and archaeological excavations was essential.

\section{The historical geography of Ardabil city}

Moqadasi sees Ardabil as the center and a district of Azerbaijan, pointing to strong beliefs for the protection of the city and its deterrence from the invading enemies. He also refers to Jame mosque and city construction which is muddier. He also expressed that: There is a mountain where one hundred and forty parasanges are all blooded and cultivated. It is said that there are seventy languages in it and the charity of Ardabil is there. "Istakhri" considers Azerbaijan as the largest city and considers its size two parasanges on both sides. He also points to its four gates, saying that it is a blessed place $^{13}$. Elsewhere, he regards Ardabil as Dar al-Amarah (house of king) of Azerbaijan and writes: "And Dabil is bigger than Ardabil and it is the Armenian city and Dar al-Amarah of Azerbaijan, just as Ardabil is the Dar al-Amarah of Arran Barda and Azerbaijan" Tousi" described Ardabil as a prosperous city with little famine and brave and religious people ${ }^{14}$. "Ibn Hawqal" considered Ardabil as the largest city in Azerbaijan, and said that "This city was a military place with native walls. It is about 30 miles wide and most of the buildings are made of mud and brick". Ardabil is larger than Maragheh and was once a place of military garrison. Dar al-Amarah, the state treasurer, and officers of the district were there ${ }^{15}$. Hamawi considers Ardabil as one of the most famous cities of Azerbaijan and states that it was the capital of the Azerbaijani states before Islam ${ }^{16}$. "Ibn Khordadbeh" mentioned Ardabil eight times, reminding Ardabil river in the season of the origin of the rivers, and only refers to the river's flow from West to East ${ }^{17}$. "Abu Dulaf" writes about Ardabil: "From there, I went to Ardabil and passed through the

\footnotetext{
${ }^{10}$ Mahmood Mousavi, Report of the Second Season of Excavation at Sheikh Safieddin Ardabili's Tomb, 1999.

${ }^{11}$ Hassan Yousefi, Report of Archaeological Speculations in the Tomb of Sheikh Safieddin Ardebili, 2006.

${ }^{12}$ Ghaffar Ghanbarzadeh and Siavash Abdollahi, Report of Archaeological Excavations at Caravanserai of Qanli Bolagh, 2006.

${ }_{13}$ Abu Ishaq Ibrahim Istakhri, op. cit., p. 155.

${ }^{14}$ Mohammad bin Ahmad Tousi, The Wonders of Being and the Wonders of Existence, 1978, p. 131.

${ }^{15}$ Abolghasem Mohammad Ibn Hawqal, op. cit., 1988, p. 476.

${ }^{16}$ Yaqut Hamawi Baghdadi, Mu'jam ul-Buldān, 2004, p. 145.

${ }^{17}$ Abu'l-Qasim Ubaydallah ibn Abdallah ibn Khordadbeh, The Book of Roads and Kingdoms, 1889, p. 164.
} 
mountains of Wisor, Qiban, Khajin, Rob, Handan and Bazin. In this place, there is a mineral of alum ${ }^{18}$. According to the view of Pietro Della Valle, "Ardabil is located in Northern Iran and it is elevated and cool like the rest of Azerbaijan. In the travelogue of Pietro Della Valle, Ardabil is named "the intersection of communication ${ }^{19}$ ". Olearius stated that "The Turks call Ardabil "Ardavil" and in foreign maps, it is called "Ardounil". It is this part of the territory of Azerbaijan that was called "Satrapean" in ancient times. He said that Ardabil is an ancient city and, for the Iranians, a famous city. Ardabil has almost the shape of circle with a diameter of about three miles ${ }^{20}$.

\section{Communication Routes in Early Centuries}

Ardabil's wide plain in the early centuries had created a considerable space for every person to inhabit, making the city important and secure. The wide plain of Ardabil city was located in the main corridor of North-South, East, West and Caucasus. The communication routes of this city to other regions in the early centuries will be described and analyzed according to historical texts.

The most important route mentioned in most of historians' and geographers' books was the route of the city to the lands of Arran and the Caucasus.

In the section related to Northern cities, under the title of Azerbaijan and Armenia, "Ibn Khordadbeh" depicts a road that diverges from the Baghdad-Khorasan highway ${ }^{21}$.Yaqoubi describes Ardabil's way to Arran as follows: "... Ardabil is the first city in the Azerbaijani cities that you see. From Ardabil to Azarbaijan, it is three days ${ }^{22}$. "Istakhri" once described Maragheh's communication route to Ardabil and from Ardabil to Arran: ... from Ardabil to Mughan is ten parasangs and from Ardabil to Khashen is eight parasangs, then to Barzand sixth parasangs. Barzand was a ruined place where Afshin rebuilt it and turned it into an urban city, settling there. From Barzad to Sader Asb, where the first hazelnut is located, is two parasangs and to Zahrkosh, where the second hazelnut is located, there are two parasangs. From there to Dularud, where the third hazelnut is located, there are two parasangs, and from those two areas, Baz and Babak city, there is one parasang ... and the way from Barzand to the Balasjan's desert and to Varsan, the last province of Azerbaijan, there are twelve parasangs" 23 "Ibn Hawqal" had shown the only way to connect Arran and Armenia with Iran and

\footnotetext{
${ }^{18}$ Abu Dulaf, Abu Dulaf's Travelogue, 1964, p.4.

${ }^{19}$ Pietro Della Valle, Della Valle's Travelogue, 2005, pp. 365-373.

${ }^{20}$ Adam Olearius, Travelogue, 1989, p. 3-492.

${ }^{21}$ Abu'l-Qasim Ubaydallah ibn Abdallah ibn Khordadbeh, op. cit., pp. 119-120.

${ }^{22}$ Al-Yaqubi Ahmad ibn Abi Yaqub, op. cit., p. 52.

${ }^{23}$ Istakhri, Abu Ishaq Ibrahim, op. cit., pp. 120-121.
} 
Azerbaijan through Ardabil in a map drawn in the $4^{\text {th }}$ century AH in his book named The Face of the Earth for Arran, Armenia and Azerbaijan ${ }^{24}$. (Fig. 1).

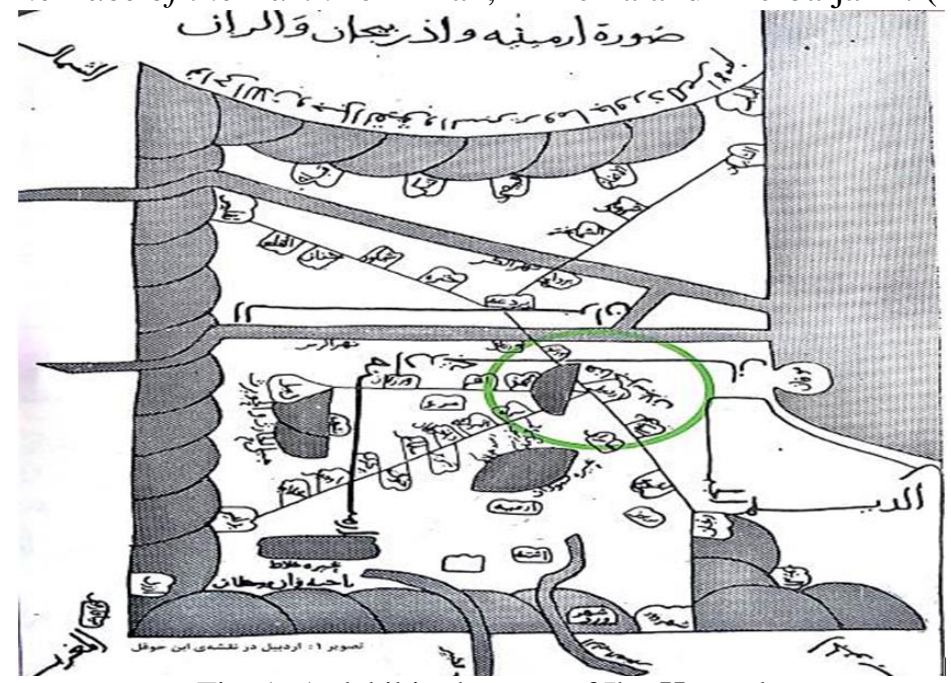

Fig. 1: Ardabil in the map of Ibn Hawqal

Qudama ibn Ja'far stated about the distance of Ardabil roads to the Northern and Caucasian regions that: ".... From Ardabil to Khan Babak there are eight parasangs, from Khan Babak to Barzand - six parasangs, from Barzand to Behlab - twelve parasangs, and from Ardabil to Mughan - four parasangs" 25 . In his travelogue on the route from Tbilisi to Ardabil, Abu Dulaf writes: "... after passing Tbilisi, "Syunik" heights of Armenia, and Babak Taghi's territory, I went to Ardabil and passed the mountains of Wisor, Qeban, Khajin, Raba, Handan and Bazin"26. According to sources and adaptation to the existing space, many buildings were built along these routes. Firouzabad Castle was built along the old communication route of Khalkhal to the West road and the Northern and Caucasian regions. This castle created multiple midway facilities by providing security. In this way, it facilitates trans-regional business communication and enhances its credibility, and this brought about a two-way communication approach between security, importance and business communication in the region ${ }^{27}$ (Fig. 2).

\footnotetext{
${ }^{24}$ Abolghasem Mohammad Ibn Hawqal, op. cit., p. 84.

${ }^{25}$ Qudama ibn Ja'far, Al-Kharaj, 1992, p. 66.

${ }^{26}$ Abu Dulaf, op. cit., 1964, p.54.

${ }^{27}$ Hamid Khanali, Studying the effects of Islamic period on Kowsar city of Ardabil province based on the archaeological study of the area, 2013, p. 196.
} 


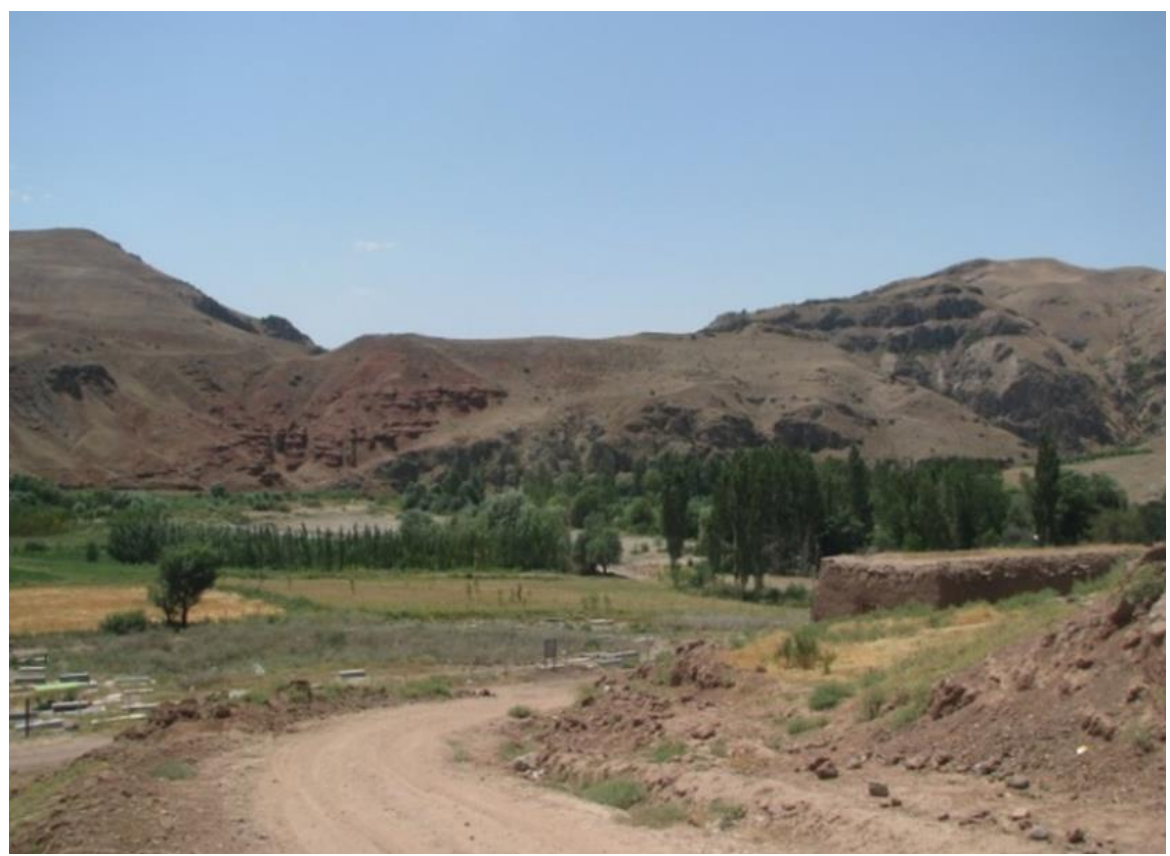

Fig. 2: Firouzabad Castle - View from the North

In the early centuries, many cities were formed along this route that is considered important in terms of cultural and commercial relations between the Caucasus and North-Western Iran (Ardabil). Along the way, these cities boosted the communication routes between Ardabil and the surrounding areas. There are sources on the export and production of these cities. The two towns named Barzand and Olten Qale Si were more important on this route than the others.

The first city was Barzand, which was on the way to Ardabil and Maragheh, and also connected Ardabil to the Northern cities of the Caucasus. Istakhri mentions the characteristic of this city as "Barzand is a clean and thriving city with its running water and much cultivation ${ }^{28 "}$. "Moqdisi " assumed Barzand as a small city and considered it as an Armenian market and useful commercial city in the Azerbaijani furnace ${ }^{29}$. "Hamawi" considered Barzand a small and unimportant city ${ }^{30}$.

The second city on this route, obtained through archaeological excavations was the ancient site of Olten Qale $\mathrm{Si}$, which has been derived from the pre-Islamic period to the Islamic period by two excavation seasons in 2003 and 2004.

\footnotetext{
${ }^{28}$ Abu Ishaq Ibrahim Istakhri, op. cit., p. 159.

${ }^{29}$ Abdu'l-Allah Muhammad ibn Ahmad Moqaddasi, op. cit., p. 387.

${ }^{30}$ Yaqut Hamawi Baghdadi, op. cit., p. 652.
} 
Oltan Qale Si is an area on the South bank of the Aras River located in less than five hundred meters West of a village called Oltan. The village is located 12 kilometers southwest of Parsabad on the way to Pars Abad to Oltan. The area itself has not been mentioned in geographical texts or historical books. The city seems to have had a name other than Olton at some point in history. It is only from the Mongol period onwards that we see its name in one of the important sources. Among the cities that have been described and positioned in ancient historical texts and sources, and their last commercial route was Ardabil and Arran, is Varsan site that is closely matched and sometimes similar. The city of Varsan seems to have been the most important city of the Aras River basin ${ }^{31}$. The city was located on the Southern shore of Aras, on the passage from where people went to Arran, and the distance to Bileqan was seven parasangs (Fig. 3).

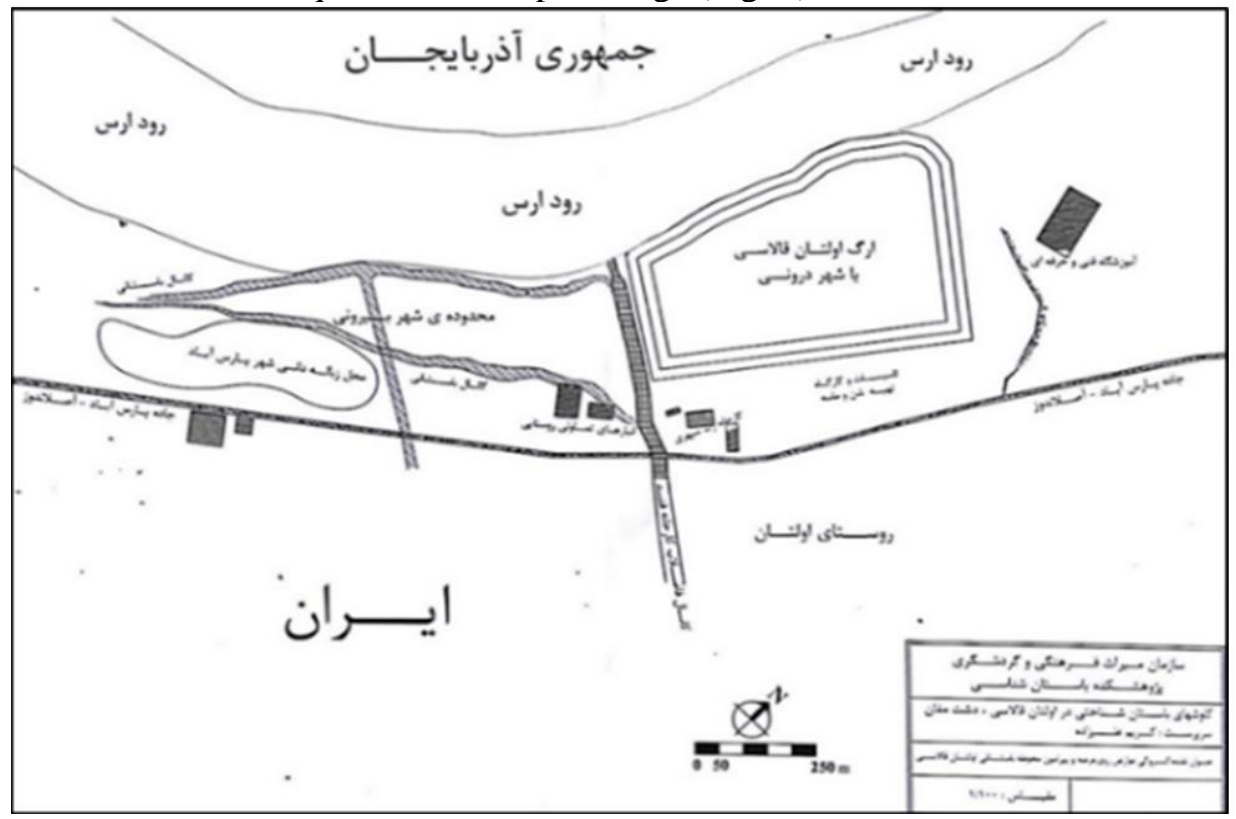

Fig. 3: Location of Oltan Qale Si in the area

Historical sources have described the distance of roads to Varsan as follow: "... and Barzand route to Balasajan desert and to Varsan, the last province of Azarbaijan, is twelve parasangs" ${ }^{\prime 32}$. Istakhri writes about Varsan as follow: "Some of the cities of Ardabil including Barzand, Varsan, Mughan, and Jabrovan were from the cities of this area. He reported the presence of fish in the areas near Aras to Varsan and exported them to Ardabil and Iraq. Ibn Hawqal writes of Varsan as follow: " Varsan is a city

\footnotetext{
${ }^{31}$ Karim Alizadeh, op. cit., pp.23-27.

${ }^{32}$ Abu Ishaq Ibrahim Istakhri, op. cit., p. 121.
} 
larger than Bileqan with more population and has markets, business centers as well as large cities of acts, inns, and fences". Table 1 lists the communication routes of Ardabil to the Caucasus based on the books of historians.

\begin{tabular}{|c|c|c|c|}
\hline $\begin{array}{l}\text { Historical } \\
\text { books }\end{array}$ & $\begin{array}{l}\text { Writing } \\
\text { date }\end{array}$ & Author's Name & Route type \\
\hline $\begin{array}{l}\text { Book of } \\
\text { Roads and } \\
\text { Kingdoms }\end{array}$ & $\begin{array}{l}280 \mathrm{AH} .\left(9^{\text {th }}\right. \\
\text { century) }\end{array}$ & Ibn Khordadbeh & $\begin{array}{l}\text { Introducing West } \\
\text { Route to Ardabil }\end{array}$ \\
\hline $\begin{array}{l}\text { Kit } \\
\text { ab al-Buldan } \\
\text { (Book of the } \\
\text { Countries) }\end{array}$ & $4 \mathrm{AH}$ & $\begin{array}{l}\text { Aḥmad ibn Abī Ya'qūb } \\
\text { al-Ya'qubi }\end{array}$ & $\begin{array}{ll}\text { Introducing } & \text { Road } \\
\text { Route } & \end{array}$ \\
\hline $\begin{array}{l}\text { Kitab al- } \\
\text { Kharaj } \\
\text { (the } \\
\text { Book of the } \\
\text { Land Tax) }\end{array}$ & $\begin{array}{l}310 \mathrm{AD} \text { or } \\
337 \mathrm{AH}\end{array}$ & $\begin{array}{l}\text { Abo Al-faraj Qudama ibn } \\
\text { Ja'far }\end{array}$ & Caucasus Road \\
\hline $\begin{array}{l}\text { Travelogue } \\
\text { of Ibn } \\
\text { Hawqal }\end{array}$ & $331 \mathrm{AH}$. & Ibn Hawqal Baghdadi & $\begin{array}{l}\text { Introducing the route } \\
\text { of Caucasian road }\end{array}$ \\
\hline $\begin{array}{l}\text { The Best } \\
\text { Divisions } \\
\text { for } \\
\text { Knowledge } \\
\text { of the } \\
\text { Regions }\end{array}$ & $375 \mathrm{AH}$. & $\begin{array}{l}\text { Abū 'Abd Allāh } \\
\text { Muhammad ibn Ahmad } \\
\underline{\text { Muqaddasi }}\end{array}$ & $\begin{array}{l}\text { Introducing the route } \\
\text { of Caucasian road }\end{array}$ \\
\hline
\end{tabular}

Table 1: Description of the routes of Ardabil to the Caucasus in the early centuries

Ardabil's route to Tabriz and the western parts of the country has also been described by historians and geographers in the early centuries. "Ibn Khordadbeh " refers to Ardabil as a city in the furnace of Azarbaijan ${ }^{33}$. "Qudama ibn Ja'far" says about Ardabil's route to Tabriz as follows: from Sarab to Nir is five parasangs, from Nir to Ardabil is 5 parasangs 34 "Istakhri" mentions the distances of the Azerbaijani cities with Ardabil as follows "... from Ardabil to Sefidrud is two stages, from Ardabil to Mianeh is two parasangs and Ardabil to Maragheh is forty parasangs ${ }^{35 " ~ I s t a k h r i ~ h a s ~ a ~ m a p ~}$ that shows Ardabil in the midst of the cities of Mianeh, Maragheh, and Zanjan (Fig. 4 and 5).

\footnotetext{
${ }^{33}$ Abu'l-Qasim Ubaydallah ibn Abdallah ibn Khordadbeh, op. cit., p. 120.

${ }^{34}$ Qudama ibn Ja'far, op. cit., p. 66.

${ }^{35}$ Abu Ishaq Ibrahim Istakhri, op. cit., p. 155.
} 




Fig. 4: Ardabil at the junction of Mianeh, Maragheh, and Zanjan 


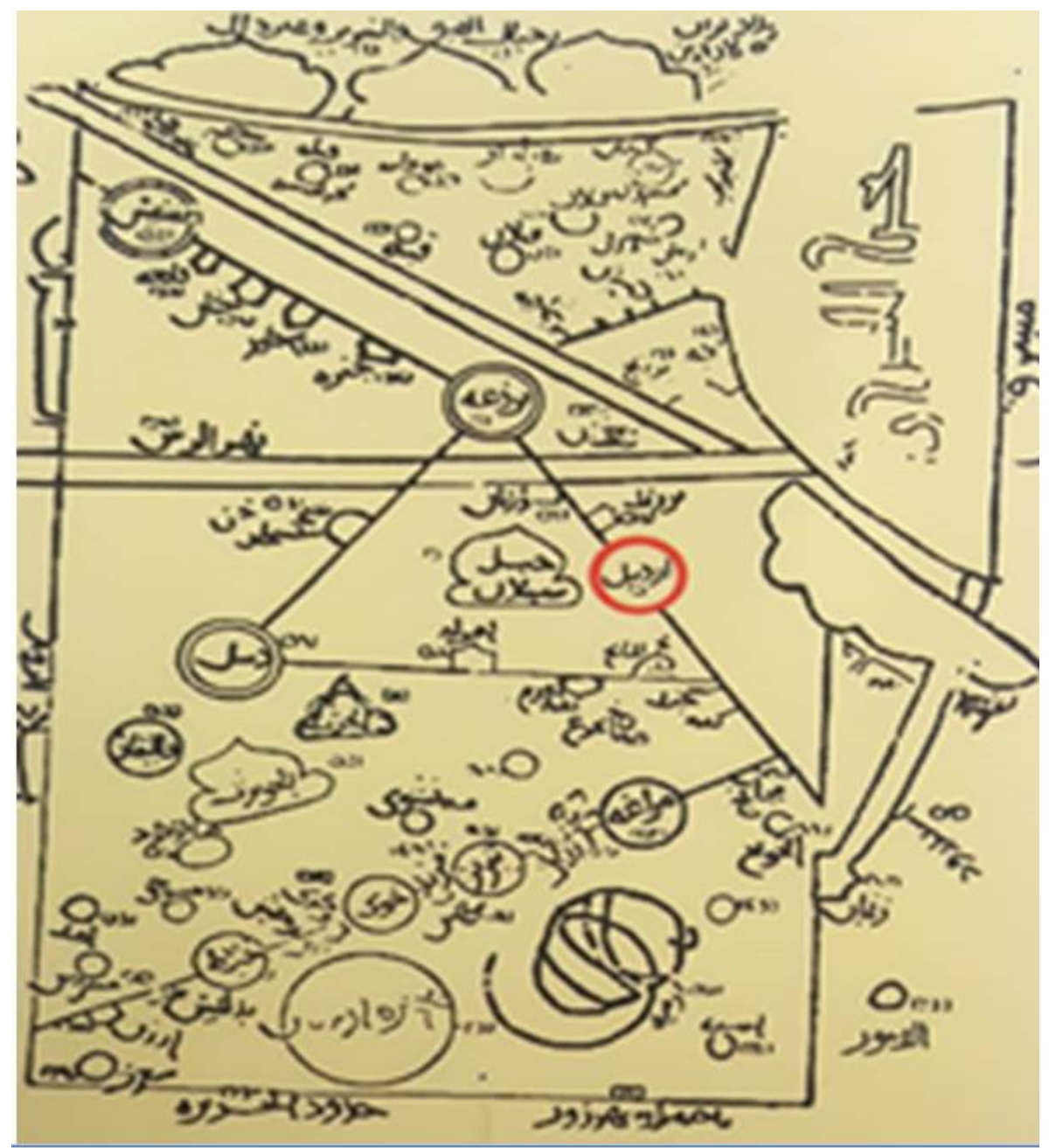

Fig. 5: Ardabil in lands of Istakhri

"Mohlabi" writes about Ardabil's route to Tabriz as it follows: "Around the West of Ardabil is a mountain with permanent snow. The people of it have a strong taste and are wicked and vicious, and the distance between Ardabil and Tabriz is 25 parasangs "Qalqashandī" mentioned the distance of Ardabil to Tabriz 25 parasangs ${ }^{36}$. Table 2 shows the route of Ardabil to Tabriz in the early centuries.

\footnotetext{
${ }^{36}$ Qalqashandi, Ahmad ibn Ali, Subh al-A shá fi Șinā 'at al-Inshā', 2005, p. 70.
} 


\begin{tabular}{|l|l|l|l|l|}
\hline $\begin{array}{l}\text { torical His } \\
\text { books }\end{array}$ & $\begin{array}{l}\text { Writing } \\
\text { date }\end{array}$ & $\begin{array}{l}\text { Author's } \\
\text { Name }\end{array}$ & Route type \\
\hline $\begin{array}{l}\text { Book of } \\
\text { Roads and } \\
\text { Kingdoms }\end{array}$ & $\begin{array}{l}\text { 280AH.(9 } \\
\text { century) }\end{array}$ & $\begin{array}{l}\text { Ibn } \\
\text { Khordadbeh }\end{array}$ & $\begin{array}{l}\text { Introducing West Route to } \\
\text { Ardabil and then Caucasian }\end{array}$ \\
\hline $\begin{array}{l}\text { Book of } \\
\text { Land Tax } \\
\text { and Art of } \\
\text { the } \\
\text { Secretary }\end{array}$ & 337 AH & $\begin{array}{l}\text { Qudama ibn } \\
\text { Ja'far }\end{array}$ & Ardabil's route to Tabriz \\
\hline $\begin{array}{l}\text { Book of } \\
\text { Roads and } \\
\text { Kingdoms }\end{array}$ & AH century & $\begin{array}{l}\text { Ibn } \\
\text { Khordadbeh }\end{array}$ & $\begin{array}{l}\text { Introducing the routes of Tabriz } \\
\text { and Caucasus road }\end{array}$ \\
\hline $\begin{array}{l}\text { Dear book } \\
\text { or Book of } \\
\text { Roads and } \\
\text { Kingdoms }\end{array}$ & 557 AH. & Mohlabi & $\begin{array}{l}\text { Introducing Ardabil Road to } \\
\text { Tabriz }\end{array}$ \\
\hline $\begin{array}{l}\text { Morning of } \\
\text { a dark night, } \\
\text { in the } \\
\text { writing } \\
\text { ritual }\end{array}$ & AH & $\begin{array}{l}\text { Ahmad ibn } \\
\text { Qli }\end{array}$ & $\begin{array}{l}\text { Introducing Ardabil Road to } \\
\text { Tabriz }\end{array}$ & \\
\hline
\end{tabular}

Table 2: Introducing Ardabil's Route to Tabriz in Early Centuries

\section{Communication ways of the city during the Ilkhanid period until the end of the Timurid period}

After the formation of Ilkhanid government, attention was paid to business and trade, having in view the necessity of historical conditions and special considerations, and special attention was paid to business from the very beginning of the government. The prosperity of Ilkhanid era was impossible without the ways in which business was conducted. Thus, the Mongol rulers had a special interest in commerce, and so some of these trade routes reached their peak in the face of security provided by Mongol rule. The key role of Azerbaijan in the trade relations of this period and the link between the East and the West by this road, on which the Indian trade routes by land and sea also joined, was crucial and determinative. During this period, Azerbaijan gained the most important role in the East-West trade relations ${ }^{37}$. At this time, the roads ending to Ardabil were very prosperous for exporting goods elsewhere. The most secure and convenient route in the relationship between Iran and the Golden Horde was the North-Western part

\footnotetext{
${ }^{37}$ Abolfazl Razavi, Trading Roads in the Ilkhanid Age, 2008, p. 70.
} 
of Iran, a route that passed through Azerbaijan, Arran and the Caucasus and reached the Golden Horde. During the Mongol era, the main route of Tabriz in the silk trade was through Ardabil to Jolfa, Khoi and Moghan plain in Ardabil and from there to Europe. Mostofi described the Iraqi route to the Northern regions of Ardabil as follows: it started from Soltanieh and after reaching Zanjan, it becomes two branches. A branch through Kaghazkonan», was in Tuman Soltanieh and Qazvin, stretching to Ardabil and from there to the provinces of Arran, Georgia, Geshtasfi, and Armenia. Elsewhere, he describes Azerbaijan's communication way to Arran and Moghan and Georgia through Ardabil: from Ardabil to "Badzhiravan" in the Moghan State and from there, it reaches "Mahmoud Abad Gavbari" by passing 20 parasangs. The other branch of the road continued from "Badzhiravan" to Aras and reached Qarabağ. This branch stretched from Qaraba $\breve{g}$ to the other cities of Arran and then reached the city of Barda after passing 19 parasangs. The recent route passed from "Barda" to "Ganjeh" and stretched from Ganjeh to "Tbilisi" in Georgia ${ }^{38}$ (Table 3).

\begin{tabular}{|c|c|c|c|}
\hline $\begin{array}{l}\text { Historical } \\
\text { books }\end{array}$ & $\begin{array}{l}\text { Writing } \\
\text { date }\end{array}$ & $\begin{array}{l}\text { Author's } \\
\text { Name }\end{array}$ & Route type \\
\hline $\begin{array}{l}\text { Mu'jam ul- } \\
\text { Buldān } \\
\text { (Dictionary } \\
\text { of Countries) }\end{array}$ & $\begin{array}{l}1218 \\
\text { AD. } 615 \\
\text { AH. }\end{array}$ & $\begin{array}{l}\text { Yaqut Al- } \\
\text { Hamawi } \\
\text { Baghdadi }\end{array}$ & $\begin{array}{l}\text { Introducing the Routes of } \\
\text { Caucasus and Khalkhal Road }\end{array}$ \\
\hline $\begin{array}{l}\text { Nuzhat Al } \\
\text { Qulub }\end{array}$ & $\begin{array}{ll} & 8 \\
\mathrm{AH} & \\
\end{array}$ & $\begin{array}{l}\text { Hamdallāh } \\
\text { Mustawfí }\end{array}$ & $\begin{array}{l}\text { Introducing the Caucasus and } \\
\text { Khalkhal Road }\end{array}$ \\
\hline $\begin{array}{l}\text { Figures of } \\
\text { the Regions }\end{array}$ & $728 \mathrm{AH}$ & Unknown & $\begin{array}{l}\text { Description of Zoroaster Travel } \\
\text { from Ardabil to Khorasan }\end{array}$ \\
\hline $\begin{array}{l}\text { Ardabil from } \\
\text { the Passage } \\
\text { of the } \\
\text { History }\end{array}$ & 1993 & Safari & The Route of Qarabağ \\
\hline
\end{tabular}

Table 3: Introducing Ardabil Roads in the Islamic Middle Ages

\section{Communication ways of the city in later centuries}

Tavernier writes about the Ardabil route to Zazan and Qazvin as it follow: "From Ardabil to Qazvin, everywhere is good". The caravan usually goes five days from Ardabil to Arion, and from there to Tarom and to Qazvin, every journey lasts two days" ${ }^{39}$. In his travelogue, Olearius describes the route from Ardabil to Soltanieh with the names of the points and located cities. Jaubert, who had traveled from Iran to Armenia during the Qajar era to

\footnotetext{
${ }^{38}$ Hamdallah Mustawfi, Nuzhat Al Qulub, 1987, pp. 180-182.

39 Jean-Baptiste Tavernier, Chardin's Travelogue,1958, p. 58.
} 
design the maps of these areas, identified four routes for traveling from Iran to Armenia to summarize his trip to Iran The first route is the one that comes to Ardabil after passing through Mianeh and Khalkhal, from there goes to Ganjeh and Elizabeth Bridge and enters Armenia ${ }^{40}$. "Etemad al-Saltanah" writes about Ardabil's situation as it follows: "This is the great land of Azerbaijan and it is on the right side of Bok Chai in one hundred and forty thousand acres on the east side of Tabriz. When Della Valle left Ardabil to meet Shah Abbas, he passed Zanjan-Firouzabad-Ardabil route and when he wanted to return, he passed Ardabil-Firoozabad-Khalkhal-Qazvin route. In his journey from Tabriz to Ardabil, Tavernier writes: "... from Tabriz to Ardabil, there is no less than 12 parasangs ${ }^{41 ", ~ " B a r t o l d " ~ w r o t e ~ a b o u t ~ A r d a b i l ~}$ road to Maragheh and Ahar: the roads to Ardabil and Maragheh were separated near Zanjan. But, at that time, there was another way to Ardabil from Mianeh ${ }^{42}$. After describing his trip to Ardabil and the importance of the city, Maraghei discusses how to travel to Maragheh. He, in a book entitled "a review of Ardabil's tour", while assessing his visit to Ardabil at that time, he mentions the village "Male" and writes: "At sunset, we reached the village of Male which is located on this side of Kettle Sain. There, we asked one of the villagers for a home". Given that Azerbaijan is located in the area in which the roads of Istanbul, Moscow, Tbilisi, Baku and Nakhchivan pass through, today it is a prestigious trading house. In describing Ardabil, Jaubert considered Ardabil a commercial warehouse for caravans where from he takes goods for Tbilisi, Darband and Baku to Tehran and Isfahan (Jaubert, 1969: 131).

\begin{tabular}{|c|c|c|c|}
\hline $\begin{array}{l}\text { Historical } \\
\text { books }\end{array}$ & $\begin{array}{l}\text { Writing } \\
\text { date }\end{array}$ & $\begin{array}{l}\text { Author's } \\
\text { Name }\end{array}$ & Route type \\
\hline $\begin{array}{l}\text { New } \\
\text { History }\end{array}$ & $\begin{array}{l}03 \mathrm{SH} \text { to } \\
0322 \mathrm{SH}\end{array}$ & $\begin{array}{l}\text { Djahangir } \\
\text { Mirza }\end{array}$ & How Russian Armies enter Ardabil \\
\hline Tavernier & $1336 \mathrm{SH}$ & $\begin{array}{l}\text { Ardabil } \\
\text { Road to } \\
\text { Qazvin and } \\
\text { Zanjan }\end{array}$ & Ardabil to Qazvin \\
\hline $\begin{array}{l}\text { Travelogue } \\
\text { of Pietro } \\
\text { della Valle }\end{array}$ & $1025 \mathrm{AH}$ & $\begin{array}{l}\text { Pietro della } \\
\text { Valle }\end{array}$ & $\begin{array}{l}\text { Introducing the Route of Caucasian } \\
\text { Road }\end{array}$ \\
\hline $\begin{array}{l}\text { Mirrors of } \\
\text { cities }\end{array}$ & $1222 \mathrm{SH}$ & $\begin{array}{l}\text { Etemad Al- } \\
\text { Saltaneh }\end{array}$ & Ardabil route to Tabriz \\
\hline
\end{tabular}

Table 4: Introducing Ardabil Roads in Late Centuries from the Viewpoint of Historians and Tourists

\footnotetext{
${ }^{40}$ Pierre Amédée Jaubert, Traveling in Armenia and Iran, 1969, pp. 365-366.

${ }^{41}$ Jean-Baptiste Tavernier, op. cit., p. 256.

${ }^{42}$ Bartold, Iranian Geographical Note, 1930, p. 268.
} 
At this time, two important factors contributed to the revival of communication ways. The first factor was the silk trade that peaked during the reign of Shah Abbas and the city of Ardabil was considered the passage of this commodity to the North-West to overseas areas. This was the second factor of the presence of Sheikh Safi al-Din Ardabili's monument that was honored by the Safavid kings and the people themselves.

The most important commodity produced in the Safavid era was silk. It was therefore one of the most important commercial products of Iran. Silk products have been produced in the Safavid period mostly in northern Iran, Gorgan, Mazandaran, Gilan and to a lesser extent in Ardabil, Shirvan Shamakhi, and around Yazd $^{43}$. Silk products were exported from Ardabil to Europe. The city became a gateway to silk export at this time. Ardabil communicated with the silk trade in two ways. 1- Guilan route to Ardabil and its exportation to Europe 2- Divisions of the Caucasian way. In tourist travelogues, the Gilan-Astara-Ardabil trade route is renowned for its Silk Road and trade, and is interpreted as a route leading to Istanbul and Izmir. For this reason, the city of Ardabil has become a gateway and gained a great deal of profit in this way. In Chardin's Travelogue, it is stated that Ardabil's location is very important because it is located on the trade route of AstraraTabriz and Lankaran, and it is through the Caucasian trade and its inner cities. In 1925, the trade was about 10,000 tons and its export was 5,700 tons $^{44}$. Della Valle says that Ardabil can be accessed to Demirqapi and Baku to Armenia, Georgia, Kurdistan and Albania. Because of its proximity to Gilan, many goods have been brought to Ardabil and taken to different lands ${ }^{45}$. Along the road from Gilan to Ardabil, there was a silk trade, which would have a direct and indirect benefit to the residents of the city. Tavernier writes about the silk trade that "people from all over Iran come to visit the Shah Safi's tomb, and this is caused by the silk trade which has made Ardabil one of the most famous cities in the country". To illustrate the importance of the silk trade, he adds: "The caravans of silk trade, sometimes reaching as many as eight hundred and nine hundred camels, have more to do with Ardabil's reputation. Due to the proximity of Gilan where silk is abundant and the close proximity to Shomakhi in which silk is also abundant and the passage is towards Istanbul and Ardabil city, the succession of merchants and businessmen is of great importance. There, as in Tabriz, all kinds of merchandise are found in extremes ${ }^{46}$.The second factor that led to the development of communication in this period was the existence of Sheikh

\footnotetext{
${ }^{43}$ Mohammad Shurmig, The Role of Gilan Silk in the Economics of the Late Shah Abbas I Early, 2015, p. 131.

${ }^{44}$ Yahya Asgari Namin, op. cit., p. 237.

${ }^{45}$ Pietro Della Valle, op. cit., p. 370.

${ }^{46}$ Jean-Baptiste Tavernier, op. cit., p. 57.
} 
Safi al-Din Ardabili's religious monument. By choosing the city as the religious and spiritual capital of the Safavids, and since the dynasty of the Safavid kings had begun to rise, it had gained popularity among the cities of that time. The Safavid kings visited the city several times each year to see the tomb of their great grandfather. The pilgrimage to the tomb of Sheikh Safi was not dedicated to Ardabil residents or his Iranian lovers, but had many pilgrims from other countries as well ${ }^{47}$. Most touristic travelogues reported monumental endowments and how the sources of these endowments were collected, together with the number of revenue they received. Certainly, to facilitate convoys crossing the city and the endowments coming from nearby towns for this monument to reach their destination both quickly and safely and to ensure their safety, the number of roads increased and improvements were made. Also, the existence of public buildings such as caravans and bridges during this period had a significant impact on the safety of roads and the convenience of caravans.

Tabriz and Ardabil cities, which are important cities of this region, have had the most important business centers of Iran since the past times because of the East-West communication route (North Silk Road).

On these routes, houses were built according to texts and travelogues. Since most of these buildings have been destroyed, only a few buildings have survived from the Safavid period. The most important mid-way and resorts monuments of this route in Ardabil province, obtained through archaeological excavations, were caravanserai of Qanlu Bolagh and then Shur Gol in which caravans entered into Arran and the Caucasians after taking rest in these areas.

The caravanserai of Qanlu Bolagh: The building is located in the village of Arshaq, which today lies on the border between Iran and the Republic of Azerbaijan. Due to its special position, it is located on the northern side of the Aras River and Ardabil, and was once the crossing point for businessmen and travelers who entered from Shamakhi (the center of Shirvan State) to Ardabil and Tabriz. On his journey from Shamakhi to Ardabil, Adam Olearius mentions a number of caravans, one of which was built by Indian businessmen, saying that this place is located near one of the Moghan's villages called Barzand, which had a special economic boom during the Mongol and Safavid times, as it was the site of Armenian trade. In fact, this area was one of the crossings points of one of the Iran's way beyond the Caucasus. As you can see on the map, the caravanserai of Qanlu Bolagh is one of the North-Western caravanserais on the Silk Road.

\footnotetext{
${ }^{47}$ Safari, Baba, Ardabil in the Transition of History, 2005, p.291.
} 




Fig. 6: The Route of Silk Road in the Safavid Period and caravanserai Inside the Route

This building was built in the style of a porch during the Safavid era and the reign of Shah Abbas. The total area of the building is 20.247 square meters and its central courtyard area is 640 square meters and its entrance door opens from the south porch. Like most buildings, it has stables, central yard, and living rooms for the passengers. Around it, there are 24 rooms in front of the courtyard that are symmetrically built on both East and West sides. The caravanserai of Qanoon Alhaq has a central courtyard with a rectangular 4-lane plan of $30 \times 25$ meters in width with seven springs at a depth of $143 \mathrm{~cm}$ and $270 \mathrm{~cm}$ and a wall thickness of $77 \mathrm{~cm}^{48}$.

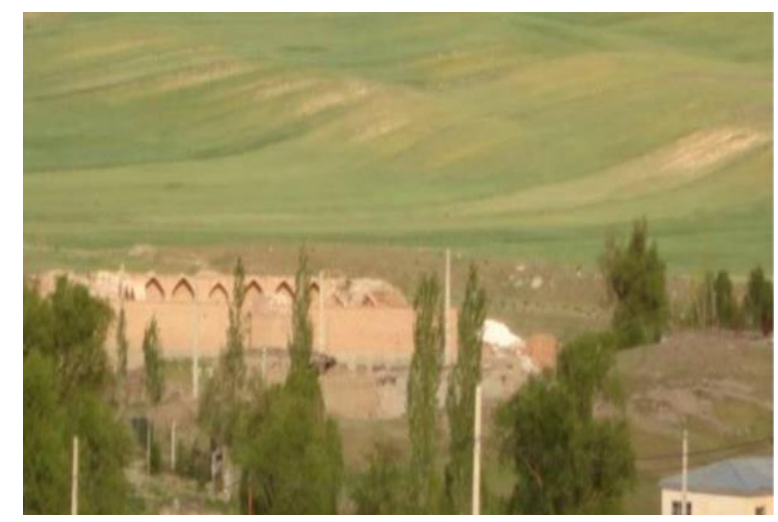

Fig. 7: View of the Moghan Plain and the caravanserai of Qanlu Bolagh

${ }^{48}$ Aydin Ghaemi Khiyavi, Thesis on Restoration of Buildings, 2008, p. 120. 


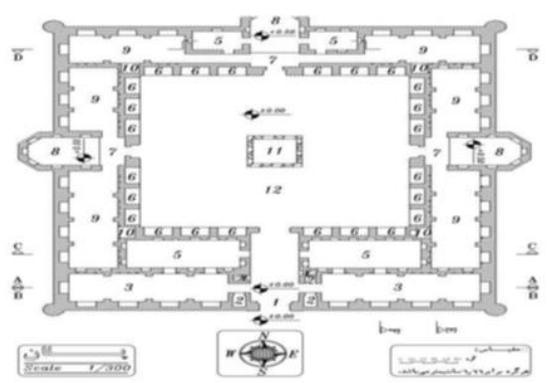

Fig. 8: Plan of the caravanserai of Qanlu Bolagh

The caravanserai of Shah Abbasi in Sain's neck is one of the midway buildings located along the Ardabil trade road to the North-West and mentioned in the Safavid era travelogue. The location of this caravanserai on this snowy and high country road shows the importance of the road in its time. According to the plan of the mountainous caravanserai of Iran, it has no yard and is covered with arch and dome. The whole building is made of stone. It is fully adapted to the climate of the region. Inside the building, the height of the entrance doors is reduced. The interconnections located in the center have relatively larger entrances than adjacent spaces. The whole building material is made entirely of stone and this type of material was present in the area. Closed and covered building on every side are features that could easily withstand constant winds and winter snow (Fig. 9).

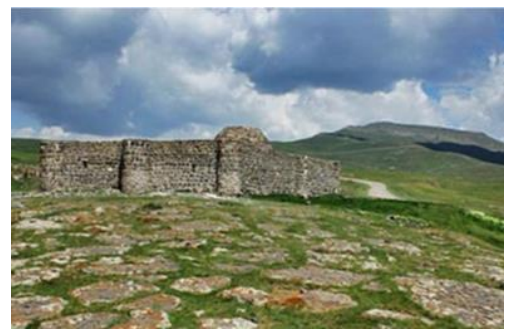

Fig 9. The caravanserai of Shah Abbasi in Sain's neck

\section{Conclusion}

In historical texts and geographers' books, research has a central role in the study of Iranian architecture and urban planning. These sources provide scholars with extensive scientific information on the structure of Islamic cities in terms of politics, economy, culture and so on. This study was based on the examination of two groups of sources, including the findings of historical written sources, and the study of travelogues along with archaeological findings with respect to environmental geographical conditions, geographical location, political and cultural boundaries. According to the introduction of numerous routes to Ardabil to other areas 
through the study of historical texts and travelogues, it is worth mentioning that the introduced routes had a great impact on the formation and survival of Ardabil. In the early centuries, the roads leading to the city were particularly prosperous. According to historians, at this time, the city was a communicative intersection connecting other points of the way together. In most of these sources, the ending routes of this city to other points are mentioned with the distances and cities located along these routes. So, the survival of the city at this time was based on strategic location. In the Middle Ages and from the Mongol invasion until the formation time of Safavids, it was established the importance of routes; communication routes were not found in historical sources, and by transferring the capital to Tabriz, historians began to mention the destruction and description of wars in their sources. Road development took place during the Safavid era. In this period, the spiritual significance of the tomb of Sheikh Safi has been mentioned for kings and people in historical sources and travelogues. Orientalist travelogues have mentioned many endowments for this monument from different parts of the country. These endowments brought enormous wealth to the caliphate. Also with the prosperity of the silk trade during the time of Shah Abbas, the city of Ardabil thus became an important communication crossroad for this product. The corridor of the Gilan state to Ardabil was a silk crossing that in addition to selling the city's own merchandise, they also received substantial profits for the city's residents through the right of way. There have been numerous references to the benefit of silk trade for this city. The importance of the silk trade was even greater than the religious tomb of Sheikh Safi. The importance of these two factors led to build mid-way buildings and providing roads such as bridges and caravans, and so on in areas leading to the city for the convenience of caravans and merchants. This lead to the increase of the importance of the city in the Safavid dynasty, so that the city prospered and the endowment increased, the accumulation of wealth through the revival of communication routes and the travel of Orientalists and tourists to this city during this period. The importance and security of trading roads are two important components which influenced each other, making Ardabil a city in the center of commercial routes in the North-East. This situation can be seen during the Islamic period from the beginning of Islam to the late Islamic centuries.

\section{List and source of illustrations:}

Fig. 1 Ardabil in the map of Ibn Hawqal, Rahman Shah Mohammad Ardabili, from Artaville to Ardabil, 2016, p. 80.

Fig. 2 Firouzabad Castle - View from the North, Hamid Khanali, Studying the effects of Islamic period on Kowsar city of Ardabil province based on the archaeological study of the area, 2013, p. 196. 
Fig. 3 Location of Oltan Qale Si in the area, Karim Alizadeh, Preliminary Report on Archaeological Excavations at Owltan Qalasi, Moghan Plain of Ardabil, 2007.

Fig. 4 Ardabil at the junction of Mianeh, Maragheh, and Zanjan, Rahman Shah Mohammad Ardabili, from Artaville to Ardabil, 2016, p. 83.

Fig. 5 Ardabil in lands of Istakhri, Abu Ishaq Ibrahim Istakhri, Book of Roads and Kingdoms, 1990.

Fig. 6 The Route of Silk Road in the Safavid Period and caravanserai Inside the Route, Hashem Hamrahi, A Comparative Study of the Architecture of Safavid Caravansaries of Azerbaijan with Isfahan Province (Case Study of Qanli Bolagh Caravanserai of Azarbayjan and Mother Shah Caravanserai of Shah Esfahan), 2014, p. 44.

Fig. 7 View of the Moghan Plain and the caravanserai of Qanlu Bolagh, photo author Fig. 8 Plan of the caravanserai of Qanlu Bolagh, Hashem Hamrahi, A Comparative Study of the Architecture of Safavid Caravansaries of Azerbaijan with Isfahan Province (Case Study of Qanli Bolagh Caravanserai of Azarbayjan and Mother Shah Caravanserai of Shah Esfahan), 2014, p. 63.

Fig. 9 The caravanserai of Shah Abbasi in Sain's neck, photo author.

\section{Bibliography:}

Hajizadeh, Karim, Investigation of Urartu Establishment Patterns in the NorthWest of Iran, Master's Degree of Anthropology, Tarbiat Modares University of Tehran, 1996.

Hatam, Gholamali, Rock tombs in the Median period, Art Quarterly, No. 52, Fall and Winter, pp. 106-118, 2003.

Kargar, Bahman, Urartu's tomb in West Azerbaijan, Archeological and history Journal, No. 2, pp. 57-55,1990.

Khamachi, Behrouz, The culture of East Azerbaijani Geography, Tehran: Soroush Publication, 1992.

Kleiss, Wolfram, Urartu architecture, translated by Gholamali Homayoon, Journal of Historical Review, No. 4, 1970.

Mollazadeh, Kazem, Med Archeology, Tehran: Samt Publication, 2015.

Naseri Somae, Hossein; Pashaei, Alireza; Sa'adati, Mohsen, Introduction and Survey of the Ancient Tomb of Gowijeh Qaleh in Maragheh, Journal of the Archeologist Message, vol. 11, No. 22, pp. 46-33,2015.

Pashaei, Alireza, Archeological Research of the Gowijeh Qaleh's castle, Master's Degree in Anthropology, Islamic Azad University, Abhar Branch (Not Published), 2015.

Piotrovsky, Boris, Urartu Civilization, Translated by Hamid Khatib Shahidi, Tehran: Andishehye-no Publication, 2004.

Sattar Nejad, Saeid, Archeological Study of Architecture in Maragheh, Master degree in Archeology, University of Mohaghegh Ardabil, 2017. 